\title{
ISOLATED PATHETICK NERVE PARESIS BY COMPRESSION FROM A DOLICHOECTATIC BASILAR ARTERY
}

\section{Case report}

\author{
Péricles Maranhão-Filho', Antonio Aversa Dutra do Souto², Jânio Nogueira ${ }^{3}$
}

\begin{abstract}
The article describes a woman with 53 year-old that has presented diplopia when looking down and adopted a tilted head position in order to read for the last six months. The neuro-ophthalmic examination shows isolated right superior oblique muscle paresis. The magnetic resonance and the angioresonance show the dolicoectatic basilar artery compressing the right ventral lateral brainstem.
\end{abstract}

KEY WORDS: trochlear nerve, dolichoectasy, basilar artery, ophtalmoplegy, compression.

\begin{abstract}
Paresia isolada do nervo patético por compressão da artéria basilar dolicoectásica: relato de caso

RESUMO - O artigo descreve uma mulher de 53 anos que há seis meses apresenta diplopia ao olhar para baixo, além de adotar postura inclinada da cabeça para ler. 0 exame neuro-oftalmológico revelou paresia isolada do músculo oblíquo superior direito. Os exames de ressonância magnética e angioressonância evidenciaram dolicoectasia da artéria basilar, que comprimia a face ventral lateral direita do tronco cerebral.
\end{abstract}

PALAVRAS-CHAVE: nervo troclear, dolicoectasia, artéria basilar, oftalmoplegia, compressão.

The term dolichoectasia is derived from "dolichos", meaning elongation and "ectasia", meaning dilatation ${ }^{1}$. Dolichoectasia of the intracerebral vessels is a rare disorder that affects the large arteries at the base of the brain ${ }^{2-4}$, most commonly the basilar artery ${ }^{3,5}$. In $1.7 \%$ of the general population, that is the only affected artery ${ }^{6}$. In a retrospective study reviewing 1440 magnetic resonance angiographies with the radiological diagnosis of vertebrobasilar dolichoectasia, Obogu et al. ${ }^{3}$, suggested specific parameters for defining this condition. Those were: basilar artery (BA) or vertebral artery (VA) diameter $>4.5 \mathrm{~mm}$ or deviation of any portion $>10 \mathrm{~mm}$ from the shortest expected course, and BA length $>29.5$ $\mathrm{mm}$ or intracranial VA length $>23.5 \mathrm{~mm}$. Compression by a dolichoectasic basilar artery (DBA) has already been involved in ocular motor nerve paresis ${ }^{6}$. Although it is less common than the compromising of the oculomotor or abducens nerves, the trochlear nerve may be involved by mechanical compression caused by dolichoectasia?.

The purpose of this case report is to present an unusual association of isolated paresis of the trochlear nerve with a DBA.

\section{CASE}

Six months ago, a 53 year-old hypertensive scholar group teacher started feeling persistent double vision when looking down. She started reading and writing with her head bent to the left. Even though she made orthoptic exercises for two months, her condition did not improve. She denies headache, vomiting, vertigo, cranial trauma, and any motor or sensitive symptom. She is not diabetic and does not use tobacco or consume alcohol.

On clinical examination she was lucid, oriented, and helped with the examination. Blood pressure (checked in both arms) was 240x120 mmhg while seated. Neuro-ophthalmic examination shows that she had no ptosis, eyelid twitch, fluttering eye movements, or eyelid fatigue after

\footnotetext{
${ }^{1} \mathrm{MD}, \mathrm{PhD}$. National Cancer Institute of Rio de Janeiro. Service of Neurology of Clementino Fraga Filho University Hospital, Federal University of Rio de Janeiro, Brazil; ${ }^{2} \mathrm{MD}$, MsC. National Cancer Institute of Rio de Janeiro. Service of Neurosurgery of Clementino Fraga Filho University Hospital, Federal University of Rio de Janeiro, Brazil; ${ }^{3} \mathrm{MD}$, Service of Neurosurgery National Cancer Institute of Rio de Janeiro, Brazil.
}

Received 3 July 2006, received in final form 19 October 2006. Accepted 13 November 2006.

Dr. Péricles Maranhão-Filho - Avenida Canal de Marapendi 1680 / 1802 - 22631-050 Rio de Janeiro RJ - Brasil. E-mail: pmaranhaofilho@ gmail.com 


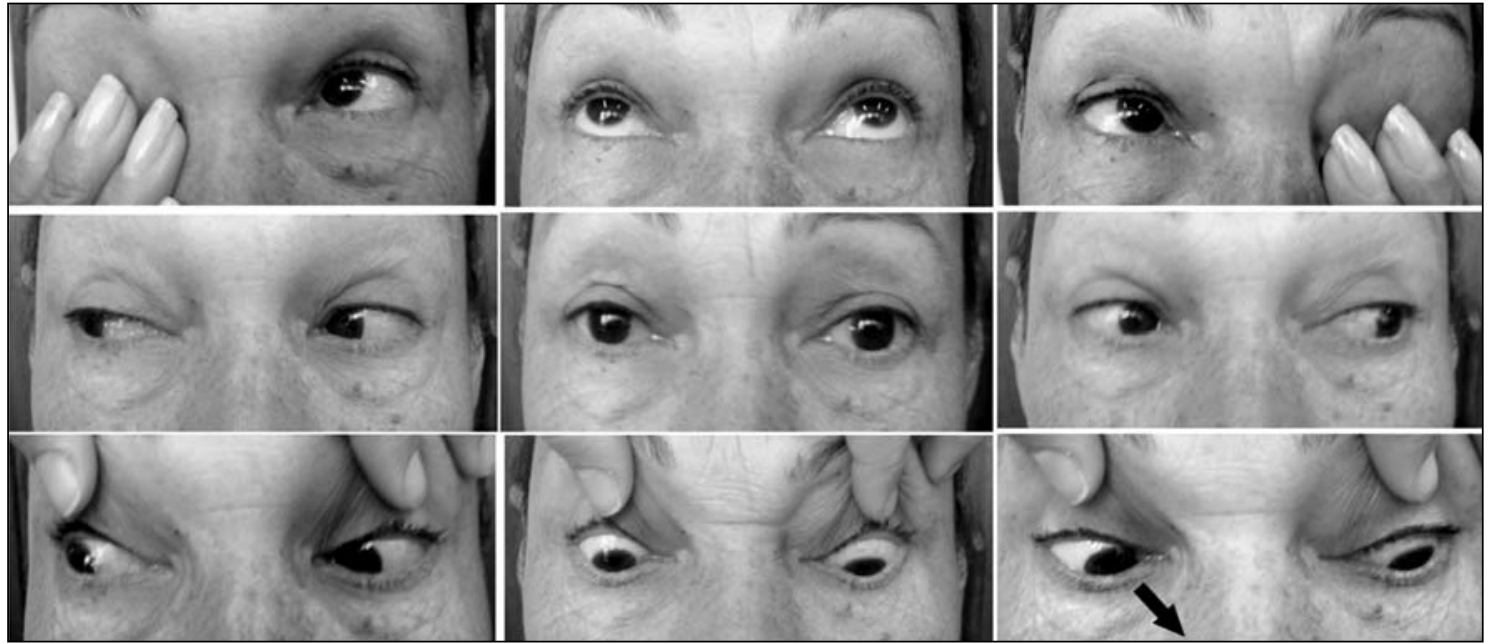

Fig 1. Extraocular movements in 9 cardinal positions. Limitation of the right superior oblique muscle on gaze down and left (arrow).
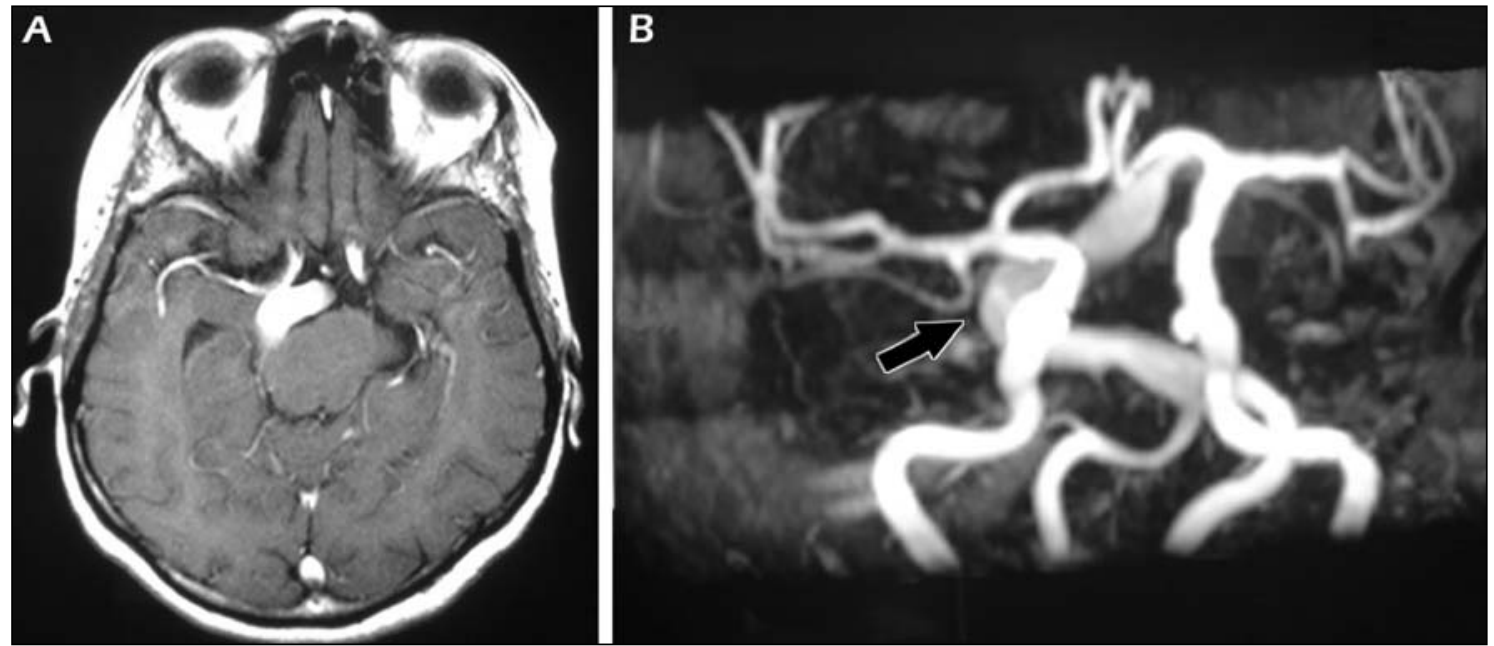

Fig 2. (A) T1W axial magnetic resonance imaging following gadolinium infusion shows a markedly enlarged basilar artery with upper pons compression. (B) Magnetic resonance arteriography shows a dolichoectatic basilar artery moved more than $10 \mathrm{~mm}$ to the rigth (arrow).

sustained upgaze. Visual acuity, color vision, pupil size, and reactivity were normal. Except for a few Gunn's crossing phenomena, the fundus oculi were normal. She complained about vertical diplopia when asked to read or write, and bent her head to the left (ear-shoulder position) in order to reduce visual discomfort. The extra ocular motility examination showed paresis of the right superior oblique muscle (Fig 1), confirmed by the Bielschowsky head-tilt test. Magnetic resonance image (MRI) and magnetic resonance angiography (MRA) showed DBA with brainstem compression (Fig $2 A$ and $B$ ). The neurosurgery team discarded the possibility that microvascular decompression would eliminate the mild symptoms. Furthermore, the patient refused the risks of major surgery. She maintains her blood pressure under control with the aid of internal medical visits.

The patient has formally given authorization for the publication of this case report

\section{DISCUSSION}

By 1664, Thomas Willis accurately described the fourth nerve: "We call these nerves the Pathetick nerves of the eyes ... the proper office of these is to move the eyes pathetically, according to the force of the passions and instinct of nature" .

Isolated trochear nerve palsy has been described as a result of the most diverse causes, such as: diabetes ischemic neuropathy ${ }^{9}$, traumas ${ }^{10}$, infectious diseases, including meningitis ${ }^{8}$, tumors ${ }^{11}$, demyelinating disease ${ }^{12}$, aneurysm ${ }^{13}$, strokes $^{14}$, and complication of intracranial surgery ${ }^{15}$.

DBA may be asymptomatic, but in $6 \%$ of this patients it may cause clinical manifestations with 
acute onset (stroke or subarachnoid hemorrhage) or with chronic progressive presentation (cranial nerve palsy, compression of the midbrain, or obstructive hydrocephalus) ${ }^{6,16}$.

Although rare, a possible site for vascular involvement of the fourth nerve would be mechanical compression as it courses towards the ventrolateral aspect of the pons, in the free border of tentorium cerebelli, by a dolichoectasic dilatation of a sclerotic vessel or a congenital aneurysm ${ }^{7}$. This was not found in larger series of pathetick paralysis, like in Rucker's ${ }^{17} 67$ cases, and in only one of Burger's 33 cases $^{7}$ when an aneurysm (not dolichoectasic artery) was found compressing the trochlear nerve.

The pathophysiology of DBA is unknown. On autopsy, the pathologic findings are rarefaction of the elastic tissue in the media with degeneration of the internal elastic lamina. Sometimes, there is an intraluminal thrombus or an atherosclerotic plaque in the ecstatic artery ${ }^{5}$. The dolichoectatic arteries have an abnormally large external diameter with a thin arterial wall ${ }^{16}$.

Some years ago, Keane ${ }^{8}$ published a study concerning 215 patients with uni or bilateral palsy of the trochlear nerve and made a review on this issue. Traumas were a cause in more than half of the patients, producing $90(51 \%)$ of the unilateral and $23(59 \%)$ of the bilateral fourth nerve palsies. Although there were many described causes, there is no mention of DBA being the causing agent.

Because of the unique visual symptom, vertical diplopia, which is worse on gaze down or near than up or distant, most of the patients look initially for an ophthalmologist's office ${ }^{8}$. The clinical diagnosis of superior oblique weakness is based on the presence of three main aspects: first, vertical diplopia is maximal when the affected (higher) eye is turned down such as when descending a flight of stairs ${ }^{9}$ or reading lying down or seated at a table, like this teacher.

Second, a characteristic compensatory head posture for writing or reading that our patient adopted. Like in other patients with the same problem, ours compensated for the torsional deviations of the eyes by tilting her head to the left, the horizontal deviations by turning her face to the right, and for vertical deviations by lowering her chin in order to facilitate fusion and to minimize double vision?
The third aspect is the Bielschowsky head-tilt test ${ }^{9}$. We asked our patient to demonstrate, using her finger, the distance between two images when her head was tilted to right, and then to the left. There was greater separation of images when she tilted her head to the right.

In conclusion, isolated paresis of the trochlear nerve is a rare condition, and even rarer when resulting from DBA compression. The neuro-ophthalmic examination is characteristic, and the combination of MRI and MRA is an effective and noninvasive means of identifying a vascular loop as the cause of the ophthalmic paresis.

Acknowledgment - The authors are in debit with Miss Iracema Breves dos Santos for passing on to us the patient and Mr. Péricles Maranhão Neto for his technical assistance and the revision of the English.

\section{REFERENCES}

1. Dorland WA. The American illustrated medical dictionary. 20.Ed. London: Saunder Company, 1944.

2. Purvin V, Kawasaki A, Zeldes S. Dolichoectatic arterial compression of the anterior visual pathways: neuro-ophthalmic features and clinical course. J Neurol Neurosurg Psychiatry 2004;75:27-32.

3. Ubogu E E, Zaidat O O. Vertebrobasilar dolichoectasia diagnosed by magnetic resonance angiography and risk of stroke and death: a cohort study. J Neurol Neurosurg Psychiatry 2004;75:22-26.

4. Kline LB, Bajandas FJ. Neuro-ophthalmology review manual. 4.Ed. Thorofare NJ: Slack Inc, 1996.

5. Pico F, Biron Y, Bousser MG, Amarenco P. Concurrent dolichoectasia of basilar and coronary arteries. Neurology 2005;65;1503-1504.

6. Tilikete C, Vial C, Niederlaender M, Bonnier PL, Vighetto A. Idiopathic ocular neuromyotonia: a neurovascular compression syndrome? J Neurol Neurosurg Psychiatry 2000;69;642-644.

7. Burger LJ, Kalvin NH, Smith JL. Acquired of the fourth cranial nerve. Brain 1970;93:567-574.

8. Keane JR. Fourth nerve palsy: historical review and study of 215 inpatients. Neurology 1993;43:2439-2443.

9. Leigh JR, Zee DS. The neurology of eye movements. 3.Ed. New York: Oxford University Press, 1999.

10. Dhaliwal AA, West AL, Trobe JD, Musch DC. Third, fourth, and sixth cranial nerve palsies following closed head injury. J Neuro-Ophthalmol 2006;26:4-10.

11. Mielke C, Alexander MSM, Anand N. Isolated bilateral trochlear nerve palsies as the first clinical sign of a metastatic bronchial carcinoma. Am J Ophthalmol 2001;132:593-594.

12. Lavin PJ M, Donahue S P. Isolated trochlear nerve palsy in patients with multiple sclerosis. Neurology 2000;55:321.

13. Agostinis A, Caverni L, Moschini L, Rottoli MR, Foresti C. Paralysis of fourth cranial nerve due to superior cerebellar aneurysm. Neurology 1992;42:457-458.

14. Keane JR. Tectal fourth nerve palsy due to infarction. Arch Neurol 2004;51:280.

15. Yoss RE, Rucker CW, Miller RH. Neurosurgical complications affecting the oculomotor, trochlear, and abducent nerves. Neurology 1968; 18:594-600.

16. Pico F, Labreuche J, Touboul P-J, Amarenco P. Intracranial arterial dolichoectasia and its relation with atherosclerosis and stroke subtype. Neurology 2003;61:1736-1742.

17. Rucker CW. Paralysis of the third, fourth and sixth cranial nerves. Am J Ophtalmol 1958;46:787-794. 